\title{
Keragaman Fenotipe Kualitatif dan Kuantitatif Itik Sikumbang Jonti sebagai Plasma Nutfah di Sumatera Barat
}

\section{Qualitative and Quantitative Phenotypic Diversity of Sikumbang Jonti Duck as Germplasm in West Sumatra}

\section{Firda Arlina*, Sabrina Husmaini, R. Rhoudha, W. R. Sardi, T. Rafian}

Fakultas Peternakan Universitas Andalas Jl. Limau Manis, Kota Padang, Provinsi Sumatera Barat, Indonesia
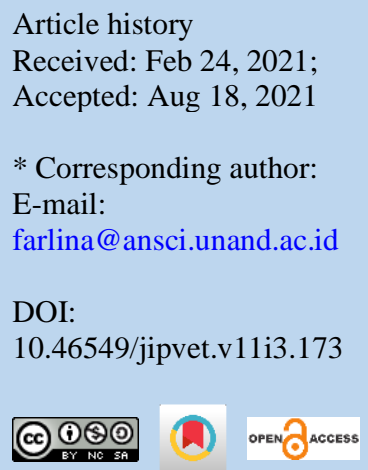

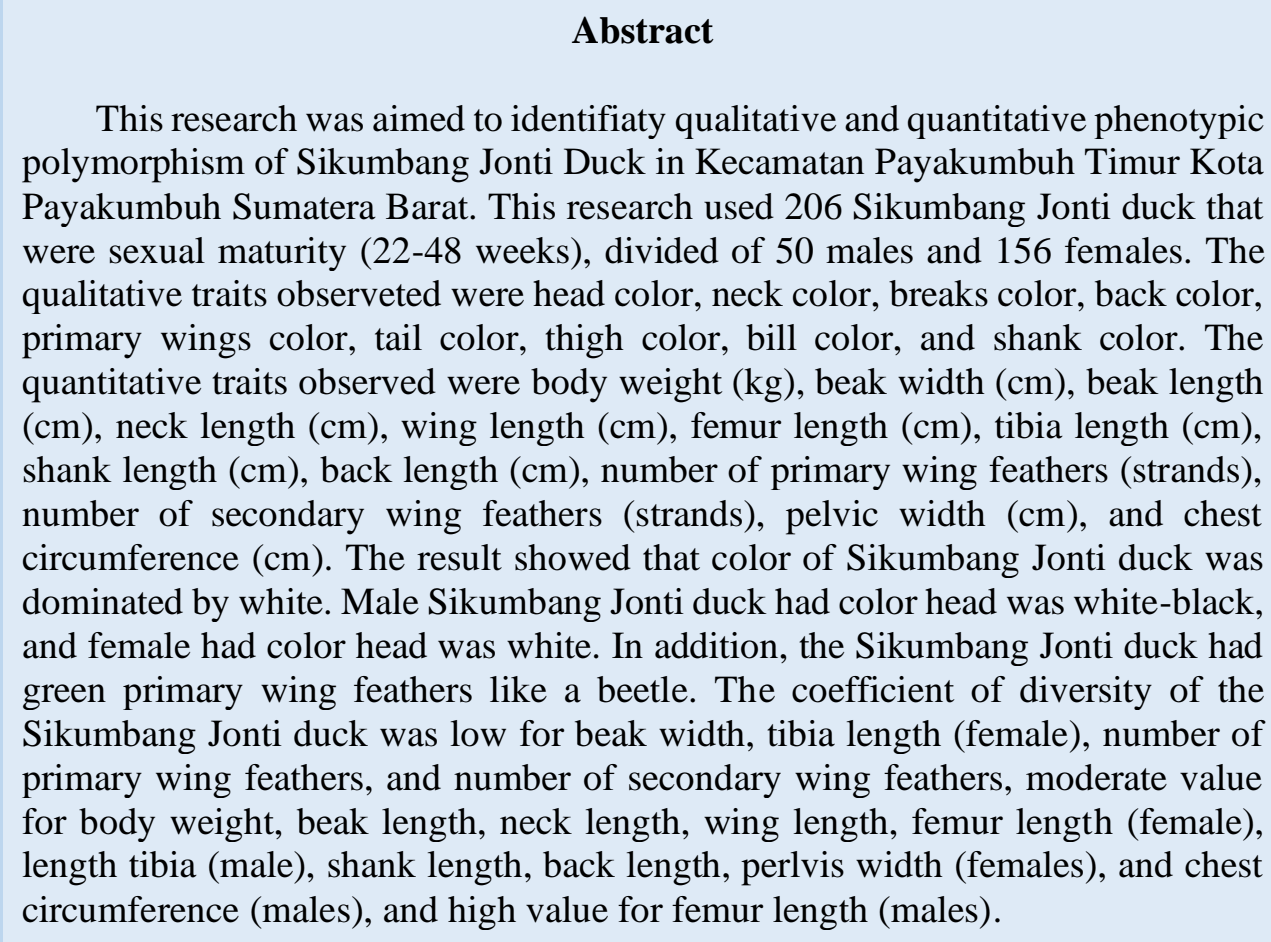

This research was aimed to identifiaty qualitative and quantitative phenotypic polymorphism of Sikumbang Jonti Duck in Kecamatan Payakumbuh Timur Kota Payakumbuh Sumatera Barat. This research used 206 Sikumbang Jonti duck that were sexual maturity (22-48 weeks), divided of 50 males and 156 females. The qualitative traits observeted were head color, neck color, breaks color, back color, primary wings color, tail color, thigh color, bill color, and shank color. The quantitative traits observed were body weight $(\mathrm{kg})$, beak width $(\mathrm{cm})$, beak length $(\mathrm{cm})$, neck length $(\mathrm{cm})$, wing length $(\mathrm{cm})$, femur length $(\mathrm{cm})$, tibia length $(\mathrm{cm})$, shank length $(\mathrm{cm})$, back length $(\mathrm{cm})$, number of primary wing feathers (strands), number of secondary wing feathers (strands), pelvic width $(\mathrm{cm})$, and chest circumference $(\mathrm{cm})$. The result showed that color of Sikumbang Jonti duck was dominated by white. Male Sikumbang Jonti duck had color head was white-black, and female had color head was white. In addition, the Sikumbang Jonti duck had green primary wing feathers like a beetle. The coefficient of diversity of the Sikumbang Jonti duck was low for beak width, tibia length (female), number of primary wing feathers, and number of secondary wing feathers, moderate value for body weight, beak length, neck length, wing length, femur length (female), length tibia (male), shank length, back length, perlvis width (females), and chest circumference (males), and high value for femur length (males).

Keywords: Duck morphometric; Germplasm; Pattern color; Payakumbuh; Sumatera barat

\section{Abstrak}

Penelitian ini bertujuan untuk mengindentifikasi keragaman fenotipe kualitatif dan kuantitatif itik Sikumbang Jonti di Kecamatan Payakumbuh Timur Kota Payakumbuh Provinsi Sumatera Barat. Penelitian ini menggunakan 206 ekor itik Sikumbang Jonti yang sudah dewasa kelamin (22 - 48 minggu), terdiri dari 50 ekor jantan dan 156 ekor betina. Sifat kualitatif yang diamati adalah warna bulu head, warna bulu neck, warna bulu breaks, warna back, warna primary wings, warna tail, warna thigh, warna bill, dan warna shank. Sifat kuantitatif yang diamati adalah bobot badan $(\mathrm{kg})$, lebar paruh $(\mathrm{cm})$, panjang paruh $(\mathrm{cm})$, panjang leher $(\mathrm{cm})$, panjang sayap $(\mathrm{cm})$, panjang femur $(\mathrm{cm})$, panjang tibia $(\mathrm{cm})$, panjang shank $(\mathrm{cm})$, panjang punggung $(\mathrm{cm})$, jumlah bulu sayap primer (helai), jumlah bulu sayap sekunder(helai), lebar pelvis $(\mathrm{cm})$, dan lingkar dada $(\mathrm{cm})$. Hasil menunjukkan warna bulu itik Sikumbang Jonti didominasi dengan warna bulu putih. Warna bulu kepala itik Sikumbang Jonti jantan berwarna putih-hitam, sedangkan itik Sikumbang Jonti betina berwarna putih. Selain itu, itik Sikumbang Jonti memiliki warna bulu sayap primer berwarna hijau seperti kumbang. Koefisien keragaman itik Sikumbang Jonti bernilai rendah untuk lebar paruh, 
panjang tibia (betina), jumlah bulu sayap primer, dan jumlah bulu sayap sekunder, bernilai sedang untuk bobot badan, panjang paruh, panjang leher, panjang sayap, panajng femur (betina), panjang tibia (jantan), panjang shank, panjang punggung, lebar perlvis (betina), dan lingkar dada (jantan), dan bernilai tinggi untuk panjang femur (jantan). Keragaman fenotipe kualitatif dan kuantitatif pada itik Sikumbang Jonti relatif seragam, kecuali pada fenotipe kuantitatif panjang femur pada itik Sikumbang Jonti jantan memiliki keragaman tinggi.

Kata kunci: Morfometrik itik; Payakumbuh; Plasma nutfah; Sumatera barat; Warna bulu

\section{PENDAHULUAN}

Indonesia merupakan salah satu negara berkembang yang memiliki plasma nutfah (FAO 2007). Beragam sumber daya genetik hewan maupun tumbuhan tersebar di beberapa daerah di Indoensia. Salah satu potensi yang dimiliki Indonesia yaitu keanekaragaman hayati sebagai sumber daya genetik yang meliputi hewan ternak, yaitu itik.

Itik merupakan salah satu komoditas peternakan yang memiliki banyak peminat baik dari segi produk daging maupun telurnya. Ternak itik juga memiliki potensi untuk dikembangkan karena mempunyai daya adaptasi yang cukup baik. Identifikasi dan karakterisasi pada sifat-sifat khas pada ternak itik merupakan salah satu upaya pelestarian keragaman genetik ternak (FAO 2007). Identifikasi dan karakterisasi sifat fenotipik ternak meliputi sifat kualitatif dan sifat kuantitatif (FAO 2007). Sifat kualitatif adalah sifat yang sangat mudah dibedakan tanpa harus mengukurnya (Noor 2008). Sifat kuantitatif adalah sifat yang harus diukur dengan cara perhitungan tertentu karena antarkelas fenotipe sangat kecil dan dikontrol oleh banyak pasangan gen yang aksinya bersifat aditif (Noor 2008).

Itik Sikumbang Jonti merupakan itik lokal di Provinsi Sumatera Barat yang memiliki potensi yang perlu digali informasi mengenai data dasar untuk pengembangbiakkannya. Hingga saat ini, informasi dasar pada itik Sikumbang Jonti masih sangat kurang. Sehingga pengembangbiakan itik Sikumbang Jonti masih belum terarah. Sehingga perlunya dilakukan identifikasi dan deskripsi pada karakteristik fenotipe kualitatif dan kuantitatif itik Sikumbang Jonti sebagai referensi dasar pada pengambilan keputusan pengembangan dan pemuliaan ternak itik Sikumbang Jonti di Provinsi Sumatera Barat.

Berdasarkan uraian tersebut untuk mengindetifikasi fenotipe kualitatif dan kuantitatif itik Sikumbang Jonti yang ada di Sumatera Barat, maka perlu dilakukan penelitian terhadap "Fenotipe Kualitatif dan Kuantitatif Itik Sikumbang Jonti. Sehingga tujuan penelitian ini adalah untuk mengetahui keragaman fenotipe kualitatif dan kuantitatif itik Sikumbang Jonti di Kecamatan Payakumbuh Timur Kota Payakumbuh.

\section{MATERI DAN METODE}

\section{MATERI}

Penelitian ini menggunakan 206 ekor itik Sikumbang Jonti yang sudah dewasa kelamin (22 - 48 minggu), terdiri dari dari 50 ekor jantan dan 156 ekor betina di Kecamatan Payakumbuh Timur. Pengambilan jumlah sampel itik berdasarkan rekomendasi FAO (2012), yang menyatakan jumlah sampel itik untuk karakteristik fenotipe adalah 100 - 300 ekor itik betina dan $10-30$ ekor itik jantan. Alat yang digunakan adalah jangka sorong, timbangan digital, pita ukur, dan kamera.

\section{METODE}

Pengambilan sampel dilakukan dengan metode purposive sampling yaitu peternak yang memelihara itik Sikumbang Jonti di Kelurahan Payobasung dan Kelurahan Koto Baru, Kecamatan Payakumbuh Timur, karena merupakan daerah yang memiliki populasi itik Sikumbang Jonti terbanyak di Provinsi Sumatera Barat.

\section{PEUBAH YANG DIAMATI}

Sifat kualitatif yang diamati pada penelitian ini berdasarkan modifikasi FAO 
Tabel 1. Sifat kualitatif pada itik

\begin{tabular}{|c|c|c|}
\hline Karakteristik & Fenotipe & Keterangan \\
\hline \multirow[t]{3}{*}{ Warna Bulu Head } & Putih & Warna bulu kepala putih \\
\hline & Hitam & Warna bulu kepala hitam \\
\hline & Putih-Hitam & Warna bulu kepala putih dan hitam \\
\hline \multirow[t]{3}{*}{ Warna Bulu Neck } & Putih & Warna bulu leher putih \\
\hline & Hitam & Warna bulu leher hitam \\
\hline & Putih-Hitam & Warna bulu leher putih dan hitam \\
\hline \multirow[t]{2}{*}{ Warna Bulu Breaks } & Putih & Warna bulu dada putih \\
\hline & Putih-Hitam & Warna bulu dada putih dan hitam \\
\hline \multirow[t]{2}{*}{ Warna Back } & Putih & Warna bulu punggung putih \\
\hline & Putih-Hitam & Warna bulu punggung putih dan hitam \\
\hline \multirow[t]{3}{*}{ Warna Primary Wings } & Hijau & Warna bulu sayap terbang hijau \\
\hline & Ungu & Warna bulu sayap terbang ungu \\
\hline & Ungu-Hijau & $\begin{array}{l}\text { Warna bulu sayap terbang ungu dan } \\
\text { hijau }\end{array}$ \\
\hline \multirow[t]{2}{*}{ Warna Tail } & Putih & Warna bulu ekor putih \\
\hline & Putih-Hitam & Warna bulu ekor putih dan hitam \\
\hline \multirow[t]{2}{*}{ Warna Thigh } & Putih & Warna bulu paha putih \\
\hline & Putih-Hitam & Warna bulu paha putih dan hitam \\
\hline \multirow[t]{3}{*}{ Warna Bill } & Kuning & Warna paruh putih/kuning \\
\hline & Merah muda & Warna paruh merah muda \\
\hline & Hitam & Warna paruh hitam \\
\hline \multirow[t]{3}{*}{ Warna shank } & Putih & Warna shank putih \\
\hline & Kuning & Warna shank kuning \\
\hline & Hitam & Warna shank hitam \\
\hline
\end{tabular}

Sifat kuantitatif yang diamati pada penelitian ini berdasarkan rekomendasi FAO (2012), Maharani et al. (2019), dan Hardjosworo et al. (2001). Beberapa cara pengukuran dapat dilihat pada Gambar 1, dan variabel pengukuran yang diamati pada penelitian adalah sebagai berikut:

1. Bobot badan diukur dengan menggunakan timbangan $(\mathrm{kg})$ dan dilakukan pagi hari sebelum ternak diberi makan.

2. Panjang paruh diukur mulai perbatasan paruh dengan kepala hingga ujung paruh diukur dengan menggunakan jangka sorong (cm)

3. Lebar paruh diukur dari sisi kanan hingga sisi kiri dengan menggunakan jangka sorong dalam satuan $(\mathrm{cm})$.

4. Panjang leher diukur dari persendian tulang tengkorak dengan tulang atlas sampai tulang torakalis pertama dengan menggunakan pita ukur $(\mathrm{cm})$.

5. Panjang punggung diukur mulai dari lekukan leher dengan punggung hingga pangkal tulang ekor dengan menggunakan pita ukur $(\mathrm{cm})$.

6. Lingkar dada diukur melingkar pada bagian dada masuk dan menempel pangkal sayap dengan menggunakan pita ukur $(\mathrm{cm})$.

7. Panjang sayap dilakukan merentangkan bagian sayap, diukur dari pangkal humerus sampai ujung phalanges dengan menggunakan pita ukur $(\mathrm{cm})$.

8. Panjang femur pengukuran tulang paha dilakukan sepanjang tulang paha. Pengukuran dilakukan dengan menggunakan jangka sorong $(\mathrm{cm})$.

9. Panjang tibia pengukuran panjang betis dilakukan sepanjang tulang betis. 
Pengukuran dilakukan dengan
menggunakan jangka sorong $(\mathrm{cm})$.

10. Panjang shank (tulang kaki) pengukuran dimulai dari persendian yang menghubungkan tibia dengan tulang kaki menggunakan jangka sorong $(\mathrm{cm})$.

11. Jumlah bulu sayap primer dihitung berdasarkan banyaknya bulu yang terdapat pada ujung sayap.

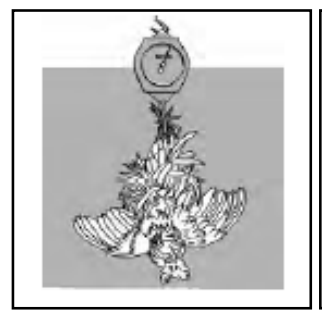

(a)

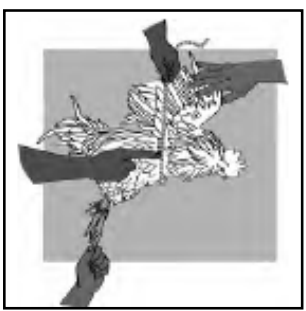

(b)

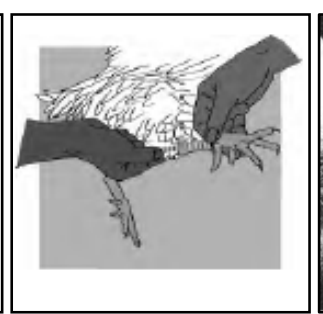

(c)

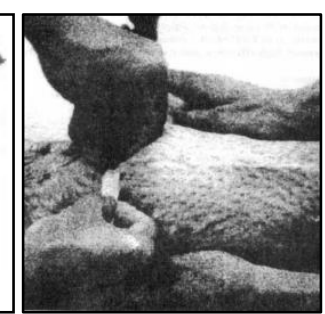

(d)

Gambar 1. Pengukuran sifat kuantitatif; (a) berat badan, (b) panjang tubuh, (c) lingkar dada, (d) rentang sayap, (e) lingkar shank (FAO 2012), dan (f) lebar pelvis (Hardjosworo et al. 2001)

\section{ANALISIS DATA}

Data fenotipe kualitatif itik Sikumbang Jonti dianalisis dengan analis statistik dekskriptif dengan menghitung persentase berdasarkan rumus Noor (2008) sebagai berikut:

Keterangan:

$$
\mathrm{P}=\frac{X i}{N} \times 100 \%
$$

\footnotetext{
$\mathrm{P} \quad=$ Jumlah Persentase fenotipe

$\mathrm{Xi} \quad=$ jumlah ternak yang memiliki warna tertentu

$\mathrm{N} \quad=$ jumlah seluruh ternak yang diamati
}

Analisa data yang digunakan untuk menganalisis sifat-sifat kuantitatif itik
Sikumbang Jonti menggunakan analisa statistik deskriptif dengan menghitung nilai rataan, simpangan baku, dan keragaman (Steel and Torrie 1993).

\section{HASIL DAN PEMBAHASAN}

\section{PEMELIHARAAN ITIK SIKUMBANG JONTI}

Sistem pemeliharaan itik Sikumbang Jonti bersifat semi intensif. Pada pagi hari ternak itik dilepaskan untuk digembalakan ke sawah untuk memakan sisa padi hasil panen, selanjutnya ternak itik dibiarkan di pekarangan kandang yang telah diberi pagar dan dimasukkan kembali pada sore hari (Gambar 2).

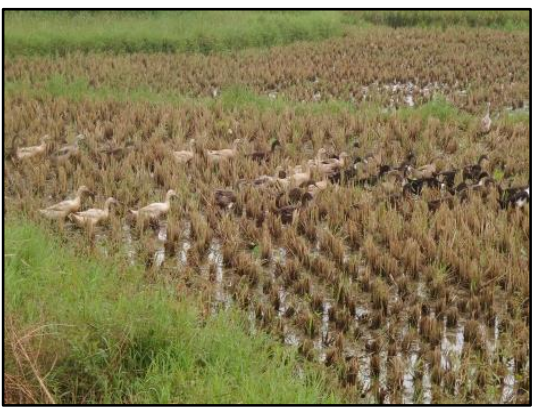

(a)

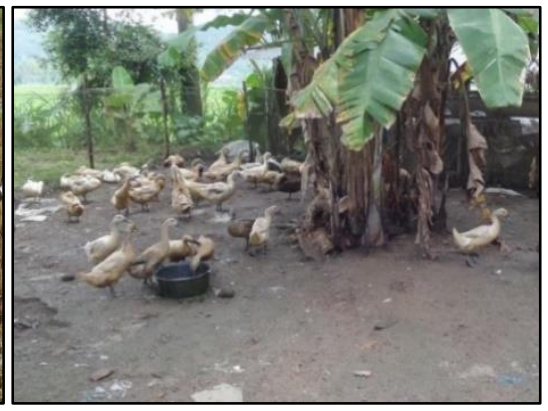

(b)

Gambar 2. Pemeliharan itik Sikumbang Jonti: (a) digembalakan di lahan sawah pada pagi hari; dan (b) digembalakan d ipekarangan kandang pada sore hari

Pemberian pakan ternak itik Sikumbang Jonti dilakukan dua kali sehari yaitu pada pagi hari dan sore hari. Penggunaan bahan pakan untuk itik Sikumbang Jonti di Kecamatan 
Payakumbuh Timur Kota Payakumbuh terlihat bervariasi, seperti dedak padi, jagung, nasi sisa, sayur, dan bekicot. Menurut Supartini and Darmawan (2016), penggunaan bekicot pada bahan pakan dapat menyuplai kebutuhan protein ternak, selain itu penggunaan bekicot dapat meningkatkan produktivitas itik dan menurunkan nilai konversi ransum. Salah satu pakan yang paling banyak diberikan oleh peternak itik adalah sisa padi panen, hal ini disebabkan lahan yang ada di Kelurahan Payobasuang dan Kelurahan Koto Baru sebagai lahan pertanian yaitu menanam padi. Sistem kandang yang dipakai oleh peternak itik Sikumbang Jonti adalah sistem kandang terbuka dengan berlantai tanah yang dibatasi pagar sekeliling.

\section{FENOTIPE KUALITATIF}

Hasil pengamatan fenotipe kualitatif itik Sikumbang Jonti jantan dan betina di Kecamatan Payakumbuh Timur Kota Payakumbuh dapat dilihat pada Tabel 2 dan Tabel 3. Hasil menunjukkan Itik Sikumbang Jonti memiliki warna bulu relatif seragam. Pada Tabel 2, itik Sikumbang Jonti jantan memiliki warna bulu kepala didominasi warna putihhitam (70\%), warna bulu leher didominasi warna putih-hitam (60\%), warna bulu dada didominasi warna putih (64\%), warna bulu punggung didominasi warna putih-hitam (60\%), warna bulu sayap primer didominasi warna hijau (64\%), warna bulu ekor didominasi warna putih-hitam (62\%), dan warna bulu paha didominasi warna putih (100\%).

Tabel 2. Persentase Sifat Kualitatif Warna Bulu Itik Sikumbang JontiJantan di Kecamatan Payakumbuh Timur Kota Payakumbuh

\begin{tabular}{llcc}
\hline \multicolumn{1}{c}{ Karakteristik } & Sifat Kualitatif & N (ekor) & Frekuensi (\%) \\
\hline Warna Bulu Head & Putih & 0 & 0 \\
& Hitam & 15 & 30 \\
Warna Bulu Neck & Putih-Hitam & 35 & 70 \\
& Putih & 20 & 40 \\
Warna Bulu Breaks & Hitam & 0 & 0 \\
Warna Back & Putih-Hitam & 30 & 60 \\
Warna Primary Wings & Putih & 32 & 64 \\
& Putih-Hitam & 18 & 36 \\
Warna Tail & Putih & 20 & 40 \\
& Putih-Hitam & 30 & 60 \\
Warna Thigh & Hijau & 32 & 64 \\
Warna Bill & Ungu & 0 & 0 \\
& Ungu-Hijau & 18 & 36 \\
& Putih & 9 & 18 \\
Warna Shank & Putih-Hitam & 41 & 82 \\
& Putih & 50 & 100 \\
& Putih-Hitam & 0 & 0 \\
& Kuning & 0 & 0 \\
& Merah muda & 0 & 0 \\
\hline & Hitam & 50 & 100 \\
\hline
\end{tabular}

Pada Tabel 3, itik Sikumbang Jonti betina memiliki warna bulu kepala didominasi warna putih (94\%), warna bulu leher didominasi warna putih (100\%), warna bulu dada didominasi warna putih (97\%), warna bulu punggung didominasi warna putih (97\%), warna bulu sayap didominasi warna hijau (77\%), warna bulu ekor didominasi warna putih-hitam (100\%), dan warna bulu paha didominasi warna putih (100\%). 
Tabel 3. Persentase Sifat Kualitatif Warna Bulu Itik Betina Sikumbang Jonti Betina di Kecamatan Payakumbuh Timur Kota Payakumbuh

\begin{tabular}{llcc}
\hline \multicolumn{1}{c}{ Karakteristik } & Sifat Kualitatif & N (ekor) & Frekuensi (\%) \\
\hline Warna Bulu Head & Putih & 147 & 94 \\
& Hitam & 9 & 6 \\
Warna Bulu Neck & Putih-Hitam & 0 & 0 \\
& Putih & 156 & 100 \\
Warna Bulu Breaks & Hitam & 0 & 0 \\
& Putih-Hitam & 0 & 0 \\
Warna Back & Putih & 151 & 97 \\
Warna Primary Wings & Putih-Hitam & 5 & 3 \\
& Putih & 151 & 97 \\
Warna Tail & Putih-Hitam & 5 & 3 \\
Warna Thigh & Hijau & 120 & 77 \\
Warna Bill & Ungu & 5 & 3 \\
& Ungu-Hijau & 31 & 20 \\
& Putih & 0 & 0 \\
Warna shank & Putih-Hitam & 156 & 100 \\
& Putih & 156 & 100 \\
& Putih-Hitam & 0 & 0 \\
& Kuning & 0 & 0 \\
& Merah muda & 0 & 0 \\
\hline & Hitam & 156 & 100 \\
\hline & Putih & 0 & 0 \\
\hline & Kuning & 20 & 13 \\
\hline
\end{tabular}

Berdasarkan warna bulu, itik Sikumbang Jonti didominasi dengan warna bulu putih. Di sisi lain, pada itik Sikumbang Jonti jantan pada bagian kepala didominasi warna putih-hitam, sedangkan pada itik Sikumbang Jonti betina memiliki warna kepala didominasi warna putih. Selain itu, itik Sikumbang Jonti memiliki ciri khas pada warna sayap primer yang berwarna hijau mengkilap layaknya kumbang (Gambar 3). Hasil ini sesuai pendapat Nova et al. (2014), yang menyatakan itik Sikumbang Jonti jantan memiliki warna bulu kepala abu-abu gelap dan betina memiliki warna bulu kepala putih, sedangkan pada bulu sayap primer berwarna biru kehitaman yang menjadi ciri khasnya.
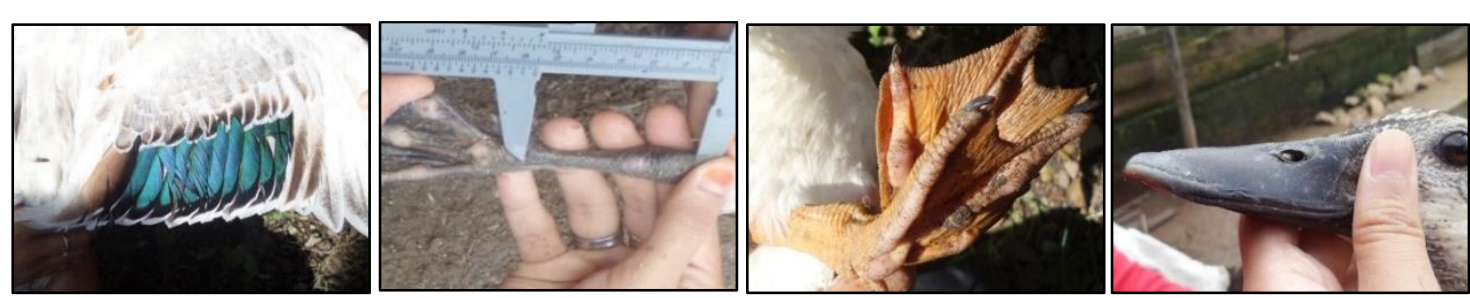

Gambar 3. Fenotipe Kualitatif Itik Sikumbang Jonti: (a) Bulu Sayap Primer Berwarna Hijau; (b) Shank Berwarna Hitam; (c) Shank Berwarna Kuning; (d) Paruh Berwarna Hitam
Itik Sikumbang Jonti memiliki warna bulu yang berbeda dengan itik lokal Sumatera Barat lainnya, seperti itik Pitalah dan itik Bayang. Menurut Maharani et al. (2019) itik Pitalah dan itik Bayang betina memiliki warna bulu lebih dominan cokelat kehitaman. Sehingga berbeda dengan itik Sikumbang Jonti yang memiliki warna bulu lebih dominan putih. Selain itu, berdasarkan penelitian Suryana et al. (2012), itik Sikumbang Jonti juga memiliki fenotipe kualitatif yang berbeda dengan itik Alabio, yang memiliki warna bulu dominan abu-abu kecoklatan. 
Dari Tabel 2 dan Tabel 3 terlihat warna kulit kaki (shank) pada itik Sikumbang Jonti jantan dan betina didominasi oleh warna hitam (82\%) dan (87\%), sisanya berwarna kulit kaki (shank) dengan warna kuning (18\%) dan (13\%). Sedangkan warna paruh pada itik Sikumbang Jonti jantan dan betina seluruhnya berwarna hitam $(100 \%)$. Keragaman warna kulit kaki (shank) dipengaruhi oleh pigmen karotenoids, melanin, dan xantophil yang muncul secara genetik dari dalam tubuh ternak, terjadinya berbagai kombinasi pigmentasi pada berbagai lapisan kaki menyebabkan warna yang berbeda-beda pada kaki itik (Mahfudz, Kismiati, and Sarjana 2005).

\section{FENOTIPE KUANTITATIF}

Hasil pengamatan fenotipe kuantitatif itik Sikumbang Jonti pada Kelurahan Koto Baru dan Payobasung Kecamatan Payakumbuh Timur Kota Payakumbuh dapat dilihat pada Tabel 4.

Tabel 4. Rataan, Standar Deviasi, dan Koefisien Keragaman Fenotipe Kuantitatif Itik Sikumbang Jonti pada Kelurahan Koto Baru dan Payobasung Kecamatan Payakumbuh Timur

\begin{tabular}{|c|c|c|c|c|c|}
\hline \multirow{2}{*}{ No } & \multirow{2}{*}{ Bagian Tubuh } & \multicolumn{2}{|c|}{ Rataan \pm SD } & \multicolumn{2}{|c|}{$\mathrm{KK}(\%)$} \\
\hline & & Jantan & Betina & Jantan & Betina \\
\hline 1 & Bobot Badan (Kg) & $1,43 \pm 0,15$ & $1,36 \pm 0,14$ & 10,71 & 10,09 \\
\hline 2 & Lebar Paruh $(\mathrm{cm})$ & $2,81 \pm 0,13$ & $2,75 \pm 0,12$ & 4,48 & 4,34 \\
\hline 3 & Panjang Paruh $(\mathrm{cm})$ & $5,97 \pm 0,47$ & $5,92 \pm 0,45$ & 7,89 & 7,58 \\
\hline 4 & Panjang Leher (cm) & $24,59 \pm 1,95$ & $24,02 \pm 1,47$ & 7,93 & 6,13 \\
\hline 5 & Panjang Sayap (cm) & $26,76 \pm 1,54$ & $25,72 \pm 2,63$ & 5,76 & 10,23 \\
\hline 6 & Panjang Femur $(\mathrm{cm})$ & $6,78 \pm 1,02$ & $6,79 \pm 0,97$ & 15,07 & 14,32 \\
\hline 7 & Panjang Tibia (cm) & $8,72 \pm 0,44$ & $8,67 \pm 0,43$ & 5,04 & 4,91 \\
\hline 8 & Panjang Shank (cm) & $6,22 \pm 0,87$ & $6,17 \pm 0,51$ & 14,06 & 8,22 \\
\hline 9 & Panjang Punggung $(\mathrm{cm})$ & $25,78 \pm 1,87$ & $24,93 \pm 2,70$ & 7,26 & 10,83 \\
\hline 10 & J.B.S. Primer (helai) & $25,70 \pm 1,24$ & $25,25 \pm 1,07$ & 4,81 & 4,25 \\
\hline 11 & J.B.S. Sekunder(helai) & $25,13 \pm 1,11$ & $24,61 \pm 0,91$ & 4,40 & 3,72 \\
\hline 12 & Lebar Pelvis $(\mathrm{cm})$ & - & $3,42 \pm 0,28$ & - & 8,23 \\
\hline 13 & Lingkar Dada $(\mathrm{cm})$ & $29,29 \pm 3,28$ & $27,93 \pm 2,65$ & 11,19 & 9,50 \\
\hline
\end{tabular}

Berdasarkan Tabel 4, koefisien keragaman Iitik Sikumbang Jonti jantan bernilai rendah untuk lebar paruh $(4,48 \%)$, jumlah bulu sayap primer $(4,81 \%)$, dan jumlah bulu sayap sekunder $(4,40 \%)$, bernilai sedang untuk bobot badan $(10,71 \%)$, panjang paruh $(7,89 \%)$, panjang leher $(7,93 \%)$, panjang sayap $(5,76 \%)$, panjang tibia $(5,04 \%)$, panjang shank $(14,06 \%)$, panjang punggung $(7,26 \%)$, dan lingkar dada $(11,19 \%)$, dan bernilai tinggi untuk panjang femur $(15,07 \%)$. Sedangkan koefisien keragaman Itik Sikumbang Jonti betina bernilai rendah untuk lebar paeuh $(4,34 \%)$, panjang tibia $(4,91 \%)$, jumlah bulu sayap primer $(4,25 \%)$, dan jumlah bulu sayap sekunder $(3,72 \%)$, dan bernilai sedang untuk bobot badan $(10,09 \%)$, panjang paruh $(7,58 \%)$, panjang leher $(6,13 \%)$, panjang sayap $(10,23 \%)$, panjang femur $(14,32 \%)$, panjang shank $(8,22 \%)$, panjang punggung $(10,83 \%)$, lebar pelvis
$(8,23 \%)$, dan lingkar dada $(9,50 \%)$. Hal ini sesuai dengan pernyataan Kurnianto (2010), penentuan klasifikasi koefisien keragaman dibagi menjadi tiga, yaitu rendah $(<5 \%)$, sedang (5-15\%), tinggi (>15\%)

Hasil fenotipe kuantitatif itik Sikumbang Jonti pada penelitian ini, bila dengan hasil penelitian Nova et al. (2014), menunjukkan rataan bobot badan, panjang paruh, lebar paruh, panjang leher, panjang sayap, panjang punggung itik Sikumbang Jonti betina pada penelitian ini lebih tinggi, tetapi lingkar dada, panjang paha, dan panjang betis lebih rendah. Perbedaan hasil penelitian ini disebabkan oleh faktor manajemen sistem pemeliharaan yang diterapkan berbeda, hasil penelitian ini menggunakan manajemen sistem pemeliharaan secara semi intensif, sedangkan pada penelitian Nova et al. (2014) menggunakan manajemen sistem pemeliharaan secara intensif. 
Perbandingan fenotipe kuantitatif itik Sikumbang Jonti betina dengan itik lokal Sumatera lainnya seperti itik Pitalah dan itik Bayang, menunjukkan itik Sikumbang Jonti betina memiliki panjang paruh, lebar paruh, dan panjang shank lebih tinggi dibandingkan itik Pitalah, tetapi memiliki panjang paruh, lebar paruh, dan panjang shank lebih rendah dibandingkan itik Bayang (Maharani et al. 2019). Selain itu, itik Sikumbang Jonti betina memiliki panjang leher terpanjang dibandingkan itik Pitalah dan itik (Maharani et al. 2019). Selain itu, itik Sikumbang Jonti memiliki bobot badan yang lebih rendah dari itik Magelang (Henrik, Purwantini, and Ismoyowati, 2018) dan itik Alabio (Suryana et al. 2014), tetapi lebih tinggi dari itik Tegal. Itik Sikumbang Jonti memiliki ukuran lebar pelvis yang lebih kecil dibandingkan itik Magelang dan itik Tegal (Henrik, Purwantini, and Ismoyowati, 2018). Berdasarkan penelitian Matitaputty and Suryana (2015), itik Sikumbang Jonti jantan dan betina memiliki panjang paruh, lebar paruh, panjang kaki, dan panjang sayap yang lebih rendah dari itik Cihateup, tetapi memiliki panjang leher dan panjang tubuh yang lebih tinggi dibandingkan itik Cihateup. Perbedaan hasil penelitian ini disebabkan oleh faktor perbedaan genetik dan bangsa antar itik. Hal ini sesuai dengan pendapat Noor (2008) dan Randa et al. (2010), perbedaan yang dapat diamati pada ternak untuk berbagai sifat disebabkan oleh faktor genetik dan faktor lingkungan.

Suparyanto, Martojo, and Hardjosworo (2004) menyatakan bahwa ukuran paruh, leher, sayap akan mencapai maksimal pada umur kisaran 13-16 minggu. Ukuran paruh memiliki fungsi biologis yang penting dalam kemampuan untuk berebut makanan. Semakin lebar paruh, maka peluang untuk menjangkau makanan akan semakin banyak.

\section{KESIMPULAN}

Keragaman fenotipe kualitatif dan kuantitatif pada itik Sikumbang Jonti relatif seragam, kecuali pada fenotipe kuantitatif panjang femur pada itik Sikumbang Jonti jantan memiliki keragaman tinggi.

\section{DAFTAR PUSTAKA}

FAO, Food and Agriculture. Organization of The United Nations. 2007. The State of the World's Animal Genetic Resources for Food and Agriculture. Rome (Italia): FAO.

FAO, Food and Agriculture. Organization of The United Nations. 2008. Guidance for Phenotypic Characterization of Chickens and Ducks. Rome (Italia): FAO.

FAO, Food and Agriculture. Organization of The United Nations. 2012. Phenotypic Characterization of Animal Genetic Resources. Rome (Italia): FAO.

Hardjosworo, P. S., A. Setioko, P. P. Ketaren, L. H. Prasetyo, A. P. Sinurat, and R. Rukmiasih. 2001. 'Perkembangan teknologi peternakan unggas air di indonesia'. Pp. 22-41 in Prosiding Lokal Karya Unggas Air. Fakultas Peternakan, IPB - Balai Penelitian Ternak, Puslitbang Peternakan.

Henrik, H., D. Purwantini, and I. Ismoyowati. 2018. 'Morphometrics and Genetic Diversity of Tegal, Magelang and Their Crossbred Ducks Based on Cytochrome b Gene'. Journal of the Indonesian Tropical Animal Agriculture 43(1):9. doi: 10.14710/jitaa.43.1.9-18.

Kurnianto, E. 2010. Ilmu Pemuliaan Ternak. Semarang (Indonesia): Universitas Dipenogoro.

Maharani, D., D. N. H. Hariyono, D. D. I. Putra, J. Lee, and J. H. P. Sidadolog. 2019. 'Phenotypic Characterization of Local Female Duck Populations in Indonesia'. Journal of Asia-Pacific Biodiversity 12(4):508-14. doi: 10.1016/j.japb.2019.07.004.

Mahfudz, L. D., S. Kismiati, and T. A. Sarjana. 2005. 'Fenotipik Dari Itik Magelang Yang Produktif'. Pp. 779-85 in Seminar Nasional Teknologi Peternakan dan Veteriner. Indonesia.

Matitaputty, P. R., and S. Suryana. 2015. 'Review on the Performances of Cihateup Duck (Anas platyrhynchos Javanica) as Genetic Resource of Local Poultry in Indonesia'. Indonesian Bulletin of Animal and Veterinary Sciences 24(4). doi: 10.14334/wartazoa.v24i4.1088. 
Noor, R. R. 2008. Genetika Ternak. Cetakan ketiga. Jakarta (ID): Penebar Swara.

Nova, T. D., A. F, and F. V. 2014. 'Karakteristik Fenotipe Itik Kumbang Jonti sebagai Itik Lokal Payakumbuh'. Pp. 52531 in Prosiding Seminar Nasional Teknologi Peternakan dan Veteriner.

Randa, S. Y., P. S. Hardjosworo, A. Apriyantono, and R. Hutagalung. 2010. 'Duck Meat Off-Odor as Affected by Different Strains and Dietary Lipids'. Jurnal Ilmu Peternakan Dan Veteriner Tropis 5(2):98-103.

Steel, R. G. D., and J. H. Torrie. 1993. Prinsip Dan Prosedur Statistika. Jakarta (Indonesia): PT. Gramedia Pustaka Utama.

Supartini, N., and H. Darmawan. 2016. 'Pemanfaatan Bekicot Sawah (tutut) Sebagai Suplementasi Pakan Itik Untuk Peningkatan Produktivitas Itik Petelur Di Desa Simorejo-Bojonegoro'. Buana Sains
16(1):1-8.

doi:

https://doi.org/10.33366/bs.v16i1.402.

Suparyanto, A., H. Martojo, and P. S. Hardjosworo. 2004. 'Kurva Pertumbuhan Morfologi Itik Betina Hasil Silang antara Pekin dengan Mojosari Putih'. JITV 9(2):11.

Suryana, R. R. Noor, P. S. Hardjosworo, and L. H. Prasetyo. 2014. 'Karakterisasi Morfologi Itik Alabio (anas Platyrhynchos Borneo) Di Wilayah Sentra Pengembangan Kalimantan Selatan'. Pp. 551-61 in Prosiding Seminar Nasional "Inovasi Teknologi Pertanian Spesifik Lokasi”. Banjarbaru (Indonesia).

Suryana, S., R. R. Noor, P. S. Hardjosworo, and L. H. Prasetyo. 2012. 'The Color Pattern of Alabio Duck (Anas Platyrhynchos Borneo) in South Kalimantan'. Journal of the Indonesian Tropical Animal Agriculture 35(2):83-89. doi: 10.14710/jitaa.35.2.8389. 